\title{
Manifestation of Langerhans cell histiocytosis in the oral cavity: The authors' experience
}

Anna Matosek-Rutkowska ${ }^{1}$, Monika Kuriata², Dorota Olczak-Kowalczyk ${ }^{3}$, Ewa Krasuska-Sławińska1

${ }^{1}$ Dental Surgical Clinic for Children, Children's Memorial Health Institute, Warsaw, Poland

2Department of Oncology, Children's Memorial Health Institute, Warsaw, Poland

${ }^{3}$ Department of Paediatric Dentistry, Institute of Dentistry, The Medical University of Warsaw, Poland

Abstract

Background. Langerhans cell histiocytosis is a rare reactive proliferative disorder marked by excess proliferation and accumulation of mononuclear phagocytes in tissues and organs. Usually, organs and systems where Langerhans cells are normally found are involved. Lesions may be limited to one system and be single- or multisite, or many systems may be involved. The etiology is not fully known. According to one of the hypotheses, immune dysfunction due to exuberant response to an unknown antigen may be the cause. The most common clinical symptoms include skin lesions, bone pain, exophthalmos, and enlarged lymph nodes, affecting the liver and spleen. Gingivitis, pocket granulation tissue, ulceration of the gingival papilla, alveolar bone atrophy leading to loosening and loss of teeth are observed in the oral cavity. The aim of the study was to determine the type and incidence of oral manifestations in patients diagnosed with Langerhans cell histiocytosis.

Methods. We evaluated patients' medical records to obtain data on the children's age at diagnosis, sex, the form of Langerhans cell histiocytosis, clinical picture (systemic and local oral symptoms), and radiological findings. Dental examinations (clinical and radiological) were performed to assess oral mucosa and periodontal tissues, and medical records were analyzed for the course and treatment of histiocytosis.

Results. The analysis included the medical records of 43 patients with Langerhans cell histiocytosis. Oral lesions in the form of gingivitis, pathological tooth mobility, and expansion of alveolar mandibular bone were observed in 7 patients. Conclusions. Langerhans cell histiocytosis may be accompanied by maxillary, gingival, and mucosal lesions.

Langerhans cell histiocytosis $•$ single-system form $•$ multisystem form $•$ oral lesions

Received: 19.08.2020, Accepted: 01.04.2021

\section{Introduction}

Langerhans cell histiocytosis $(\mathrm{LCH})$ is a rare reactive proliferative disorder. It affects 1: 200,000 children, with slightly increased prevalence in females [1, 2, 3, 4, 5, 6]. Although it may develop at any age, it is most likely to occur in children between one and three years of age [1,7]. It was reported that $\mathrm{LCH}$ is more prevalent among Hispanics and less common in black children [8].

$\mathrm{LCH}$ is caused by increased proliferation and accumulation of phagocytes derived from a common stem cell with a Langerhans cell phenotype [1, 3, 4, 6, 7, 8, 9]. Since these cells are characterized by the presence of Birbeck granules and strong expression of the CD1a antigen, the diagnosis involves immunohistochemistry (S-100 and CD1a assays) in addition to histopathology $[5,6]$. The etiology is not fully known. According to one hypothesis, immune dysfunction due to exuberant response to an unknown antigen may be the cause. Another hypothesis assumes that viral or bacterial infection is a factor stimulating Langerhans cell proliferation. However, that hypothesis is called into question by the observed lack of improvement after antibacterial and antiviral treatment [1]. Inflammatory infiltration and local and systemic cytokine storm in LCH support the inflammatory etiology of the disease. However, an increasing number of studies point to the role of somatic BRAFV600E mutations in immature Langerhans cells, which was confirmed in more than half of the cases $[10,11]$. As a result of the BRAF V600E mutation, MAP kinases (MAPKs) induce uncontrolled growth and division of Langerhans cells [12]. In addition to BRAF V600E, other BRAF activating mutations, mutations in MAP2K1 exons 2 and 3 , and rare ARAF mutations-which are also 
MAPK pathway genes-have been observed in LCH [13]. A hypothesis has been put forward that the proliferative status of the precursor cell, in which MAPK-activating somatic mutations develop, determine the clinical extent and severity of the disease [14].

Currently, many authors believe that the presence of activating somatic MAPK mutations in resilient myeloid precursor cells is the basis for defining $\mathrm{LCH}$ as a myeloid neoplastic disorder [14, 15].

Usually, the disease process involves areas of the body where Langerhans cells are found physiologically [1, 3, 4, 6, 7, 8]. Granulomatous lesions containing langerinpositive histiocytes (CD207+) and inflammatory infiltrations develop in these areas. The disease may involve one body system (single-system LCH), with one or multiple disease foci, or many systems and organs (multi-system LCH) [16, 17]. Single-system manifestations were reported in $70 \%$ of children with LCH [8].

In most cases (about $80 \%$ ), the bones (most often the skull, followed by the hip/pelvic bone, the femur and ribs), skin (33\%), pituitary gland (25\%), liver (15\%), spleen $(15 \%)$, and the lungs and lymph nodes are involved [1, 2, 3, 6, 18, 19]. The oral cavity is considered a rare location for lesions [20]. At this location, LCH may manifest itself in pain, gingival inflammation and bleeding, increased tooth mobility and their loss, mucosal oedema and ulceration, pathological bone fractures, and premature tooth eruption [4, 6, 21, 22, 23]. These manifestations may be misdiagnosed as acute periodontitis [5]. Radiological skeletal findings reveal osteolytic bone lesions with or without periosteal reactions [23].
Diagnosis of $\mathrm{LCH}$ is based on clinical symptoms, histopathology, immunochemistry (CD1 and CD207), and radiology (CT, MRI, bone scintigraphy) [7, 15, 24]. The prognosis depends on several factors, such as age, involvement of risk organs (bone marrow, liver, spleen), and the degree of their damage $[11,24]$. Single-system LCH has an excellent prognosis. Survival rate is up to $100 \%$, with five-year recurrence rate $<20 \%$. Localized form may even resolve spontaneously. The survival rate in multisystem $\mathrm{LCH}$ involving organ risk is less than $77 \%[20,25,26]$. The treatment of histiocytosis involves chemotherapy, radiation therapy, surgical intervention, and the use of high doses of glucocorticosteroids [24, 27].

The aim of the study was to determine the type and incidence of oral manifestations in patients diagnosed with Langerhans cell histiocytosis.

\section{Materials and Methods}

We conducted a retrospective analysis of $\mathrm{LCH}$ cases diagnosed and treated in the Department of Oncology and Dental Surgical Clinic for Children at the Children's Memorial Health Institute between 1996 and 2018. Patients' medical records were analyzed to obtain data on the age at diagnosis, sex, $\mathrm{LCH}$ form, clinical picture (systemic and local oral symptoms), and radiological findings. Clinical dental examination was performed in each patient at the initial stage of diagnosis of the underlying disease to assess dentition, periodontal tissues (gingivitis, tooth mobility, root exposure), and oral mucosa. Panoramic radiograph, CT, and bone scintigraphy were performed in the case of suspected

Table 1. Characteristics of patients with Langerhans cell histiocytosis included in the study

\begin{tabular}{|c|c|c|c|c|}
\hline \multirow[t]{2}{*}{ Parameters } & & \multirow{2}{*}{$\begin{array}{l}\text { Total study group } \\
\text { single-system } \\
\mathrm{n} / \%\end{array}$} & \multicolumn{2}{|c|}{ LCH form } \\
\hline & & & & \\
\hline \multicolumn{2}{|r|}{ Total } & $43 / 100 \%$ & $34 / 79.1$ & $9 / 20.9$ \\
\hline \multirow[t]{2}{*}{ Sex } & male & $25 / 58.1 \%$ & 19 & 6 \\
\hline & female & $19 / 41.9 \%$ & 15 & 3 \\
\hline \multirow[t]{3}{*}{ Age } & $\leq 3$ years & $18 / 41.9 \%$ & 12 & 6 \\
\hline & $>3-10$ years & $13 / 30.2 \%$ & 11 & 2 \\
\hline & $\geq 10$ years & $12 / 27.9 \%$ & 11 & 1 \\
\hline \multirow[t]{6}{*}{ System } & bones & $38 / 88.4 \%$ & 31 & 7 \\
\hline & skin & $11 / 25.6 \%$ & 3 & 8 \\
\hline & lungs & $5 / 11.6 \%$ & 0 & 5 \\
\hline & pituitary gland & $4 / 9.3 \%$ & 0 & 4 \\
\hline & neck lymph nodes & $2 / 4.6 \%$ & 0 & 2 \\
\hline & liver & $1 / 2.3 \%$ & 0 & 1 \\
\hline
\end{tabular}


bone manifestations (pain or tingling, bone expansion, tooth loosening, signs of periodontal destruction). Diagnosis was confirmed based on immunostaining for CD1a and S100, using a standard procedure in all selected cases. In some patients, the diagnosis was supplemented with biopsy of the gingival mucosal lesion.

\section{Results}

Medical records of 43 out of 44 patients with Langerhans cell histiocytosis were included in the study. One patient was excluded from the study due to the lack of dental examination as part of the diagnostic process. Age at diagnosis ranged between 0.33 and 16.33 years (mean $5.95 \pm 4.66$ years). Study group characteristics, including age at $\mathrm{LCH}$ diagnosis, sex, clinical form of $\mathrm{LCH}$, as well as organs and systems involved, is presented in the form of a table (Tab. 1). Of 34 cases of single-system LCH, 31 (91.2\%) involved bones, and 3 involved the skin (7.8\%). Multisystem LCH most often involved the skin (8/9), followed by the bones (7/9) and lungs $(5 / 9)$. Bone manifestations usually occurred in the craniofacial region ( $n=23)$, including the skull $(n=11)$, mandible/maxilla ( $n$ $=7)$, orbit $(n=6)$, and zygomatic bone $(n=1)$. Less common locations included the spine $(n=8)$, long bones $(n=7)$, pelvis

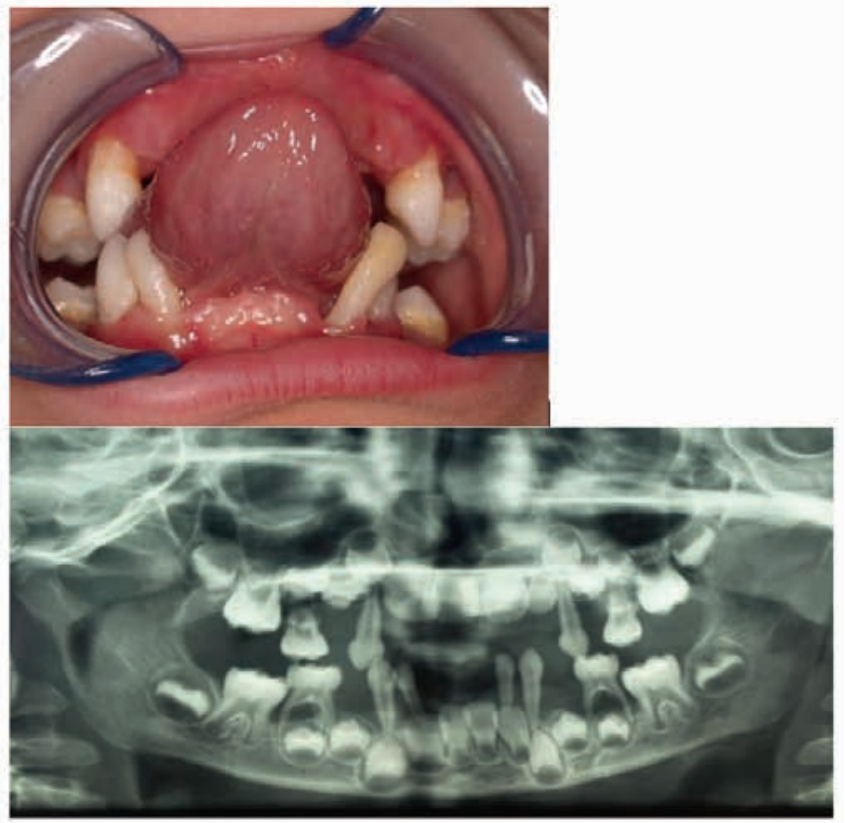

Figure 1. A 4-year-old patient. Premature loss of incisors and first maxillary and mandibular molars, generalised decrease in the translucency of the alveolar maxillary and mandibular bone with pronounced bone atrophy in the region of right mandibular cuspid and second mandibular molars, as well as root resorption of second mandibular molars
( $n=2)$, clavicle $(n=2)$ and ribs $(n=1)$. Diabetes insipidus (DI) was reported for four patients. Oral lesions in the form of gingivitis, pathological tooth mobility or expansion of the alveolar mandibular bone were observed in seven patients (Table 2, Figures 1-3). One patient was diagnosed with LCH based on histopathology of a gingival biopsy specimen.
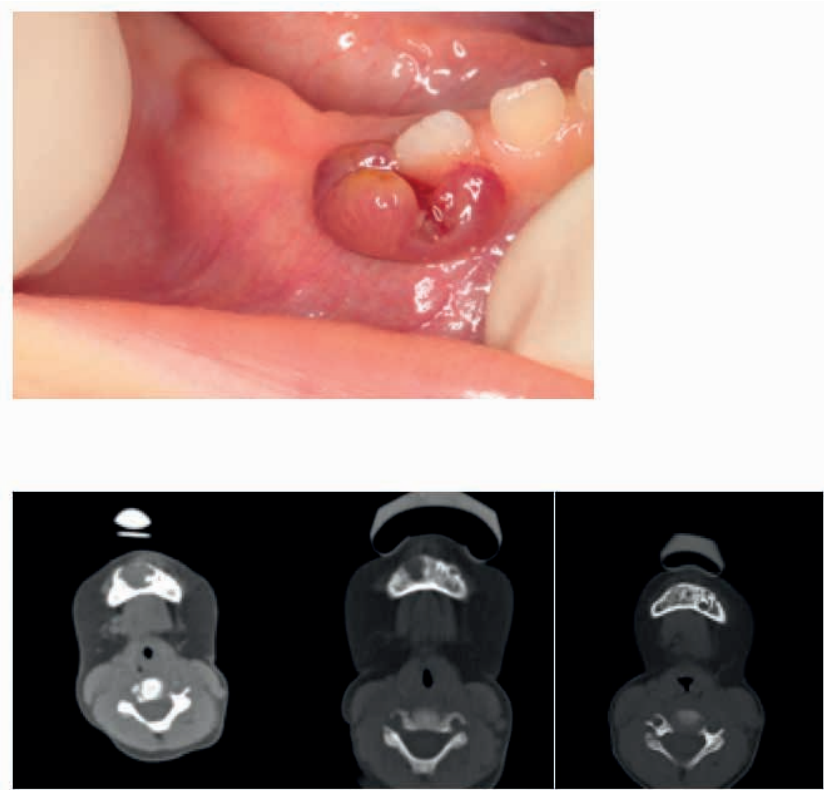

b

C

Figure 2. A 10-month-year-old patient. Alveolar mandible expansion in the region of teeth 81-83 in the single-system LCH. Image of oral cavity lesions on computed tomography before treatment (a), 6 months after the start of treatment (b) and after completion of the therapy (c)

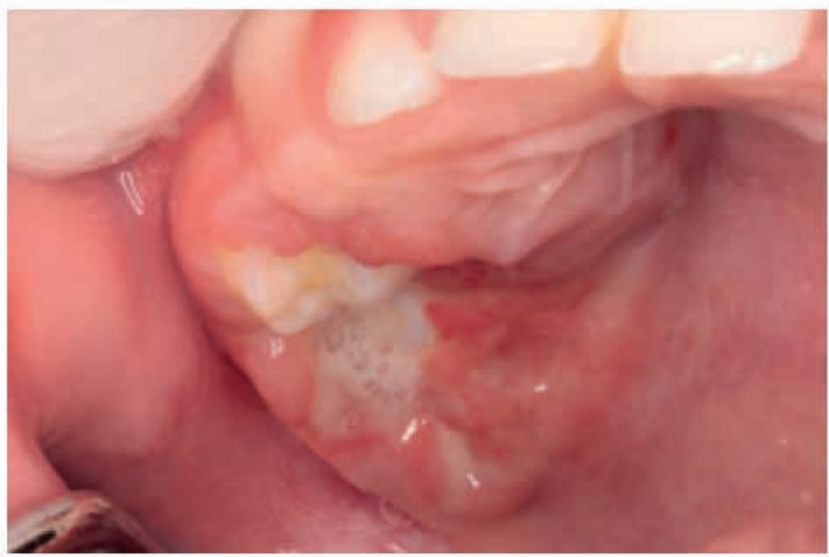

Figure 3. A 1,5 -year -old patient. Ulcer-like palatal lesions in the region of molars in the multi-system $\mathrm{LCH}$ 
Table 2. Clinical and radiological symptoms in patients diagnosed with $\mathrm{LCH}$

\begin{tabular}{|c|c|c|c|c|c|c|c|}
\hline \multirow{3}{*}{$\begin{array}{c}\text { Pa- } \\
\text { tient } \\
\text { no. } \\
\\
1\end{array}$} & \multirow{3}{*}{$\begin{array}{c}\text { Age at LCH } \\
\text { diagnosis in } \\
\text { years (age at } \\
\text { the onset of } \\
\text { oral lesions) } \\
0.33\end{array}$} & \multirow{3}{*}{$\begin{array}{l}\text { Sex } \\
\text { female }\end{array}$} & \multirow{3}{*}{$\begin{array}{c}\begin{array}{c}\text { Diagnosed } \\
\text { form of LCH }\end{array} \\
M-S\end{array}$} & \multicolumn{2}{|c|}{ Clinical symptoms of stomatognathic system } & \multirow{3}{*}{$\begin{array}{c}\begin{array}{c}\text { Radiological symp- } \\
\text { toms }\end{array} \\
\text { osteolytic bone lesions }\end{array}$} & \multirow{3}{*}{$\begin{array}{l}\text { Other organs/sys- } \\
\text { tems, symptoms }\end{array}$} \\
\hline & & & & Clinical picture & Location & & \\
\hline & & & & $\begin{array}{c}\text { third degree loose } \\
\text { mandibular teeth, vivid } \\
\text { red gingiva, bleeding on } \\
\text { compression }\end{array}$ & $\begin{array}{l}\text { alveolar part of the } \\
\text { mandible }\end{array}$ & & \\
\hline 2 & 0.87 & male & S-S bone & $\begin{array}{l}\text { alveolar mandible } \\
\text { expansion in the region } \\
\text { of teeth } 81-83\end{array}$ & unilateral mandible & $\begin{array}{l}\text { osteolytic right man- } \\
\text { dibular lesion }\end{array}$ & no other symptoms \\
\hline 3 & 1.01 & male & S-S skin & $\begin{array}{l}\text { gingivitis, loosening of } \\
\text { teeth } 71,72,81\end{array}$ & gingiva & none & $\begin{array}{c}\text { typical skin lesions on } \\
\text { the chest }\end{array}$ \\
\hline 4 & 1.15 & male & M-S & $\begin{array}{l}\text { gingivitis, } \\
\text { tooth loosening }\end{array}$ & palate & none & $\begin{array}{l}\text { papular lesions on the } \\
\text { skin, exophthalmos, } \\
\text { liver }\end{array}$ \\
\hline 5 & 1.44 & female & M-S & $\begin{array}{l}\text { ulcer-like palatal lesions } \\
\text { in the region of molars, } \\
\text { root exposure and loos- } \\
\text { ening of teeth } 74,75\end{array}$ & $\begin{array}{l}\text { bilaterally involved } \\
\text { palate in the region of } \\
\text { molars and the alveolar } \\
\text { part of the mandible }\end{array}$ & none & skull bones, orbit, lungs \\
\hline 6 & 2.16 & male & M-S & $\begin{array}{c}\text { periodontal destruction, } \\
\text { exposed bifurcation of } \\
\text { the first primary maxil- } \\
\text { lary and mandibular } \\
\text { molars }\end{array}$ & maxilla and mandible & $\begin{array}{l}\text { osteolytic lesions in the } \\
\text { region of roots of first } \\
\text { primary molars }\end{array}$ & $\begin{array}{l}\text { skin lesions on the } \\
\text { head, abdomen and } \\
\text { back, liver infiltration }\end{array}$ \\
\hline 7 & 4.16 & female & M-S & $\begin{array}{c}\text { mandibular expansion } \\
\text { in the region of tooth } 46 \\
\text { with gingival thickening } \\
\text { and reddening in this } \\
\text { region }\end{array}$ & $\begin{array}{l}\text { Unilaterally involved } \\
\text { mandible } \\
\text { in the region of right } \\
\text { molars }\end{array}$ & $\begin{array}{l}\text { osteolytic lesions in the } \\
\text { region of permanent } \\
\text { molars and second pri- } \\
\text { mary molars, resorption } \\
\text { of distal root of tooth } \\
85, \text { partial resorption of } \\
\text { tooth bud } 45\end{array}$ & $\begin{array}{l}\text { neck lymph nodes, } \\
\text { mediastinum, orbital } \\
\text { tumour, skull bones, } \\
\text { non-specific lesions in } \\
\text { the lungs, liver }\end{array}$ \\
\hline
\end{tabular}

\section{Discussion}

Langerhans cell histiocytosis is a rare disease occurring mainly in children and adolescents. The etiology is not fully known $[3,4,6]$. The variety of clinical manifestations, as well as the specificity and number of organs potentially involved by LCH may cause diagnostic difficulties [1, 2, 3, 6, 18, 19]. Descriptions of many initially misdiagnosed LCH cases may be found in the available literature [3]. We observed similar diagnostic difficulties in our study group.

Peak incidence is between one and four years of age [7, 12]. A total of $41.9 \%$ of our patients were under three years old. LCH may present as a single- or multisystem disease. It may be concluded based on the available literature that single-system LCH (S-S LCH) is more common [7, 12]. This was also confirmed in our study, which showed that singlesystem LCH accounted for $79.1 \%$ of cases. Most patients with histiocytosis present with bone (80\%) and skin (60\%) involvement. Craniofacial LCH is reported in $20 \%$ of patients $[5,7,18,19]$. In our study group, bone and skin manifestations occurred in $88.4 \%$ and $25.6 \%$ of children, respectively. Oral lesions were observed in $15.9 \%$ of patients. The initial oral symptoms may be nonspecific, and they often occur in the form of gingivitis, mucosal ulceration, and radiological findings of maxillary and mandibular bone defects [1, 2, 3, $5,6,7]$. They may be the initial or the only manifestation of the disease $[3,5]$. This was also confirmed in our study. We observed single-site LCH with gingivitis and tooth loosening, as well as cases with initial manifestations in the form of oral lesions. Martinez et al. emphasized that oral manifestations of LCH involve the gingiva in more than half of cases, as also confirmed by our findings $[2,3,6]$.

Some authors point to the frequent occurrence of craniofacial bone defects with accompanying ulceration of the surrounding mucosa [27]. In addition to radiologically confirmed bone manifestations, we also observed mucosal hyperplasia without ulceration in our patients, which 
corresponds to the findings presented by Kilic [27]. Bone loss is also accompanied by increased tooth mobility, which often leads to their loss [2, 4, 5, 27]. This was the case of three of our patients, whose osteolytic maxillary and mandibular lesions caused tooth loss as a result of exposure and premature resorption of roots. Oral lesions cannot be neglected as they may prove to be an important diagnostic criterion in many diseases. Examples include the destruction of the periodontium in agranulocytosis or cleft lip and palate caused by defects in the primary cilia [28, 29].

The treatment of Langerhans cell histiocytosis involves surgery, chemotherapy, local and systemic glucocorticosteroid therapy, bone marrow transplant, and immunoglobulin therapy $[7,30]$. The choice of treatment method depends on the type of lesions, organs involved, and the form of $\mathrm{LCH}$. Our patients were treated with vinblastine (VBL) and encorton for one year. In the case of progression and new foci, cladribine and ARACE were used as second-line therapy. Methotrexate is used for several months or even years as maintenance treatment in patients with multisite LCH.

All patients who completed treatment require long-term follow-up due to the possible recurrence and increased risk of other cancers [7]. The patients of the Outpatient Clinic of Oncology at the Children's Memorial Health Institute are followed up for at least 10 years, and even until the age of 18 in the case of early childhood onset. Frequent recurrence is observed during such a long follow-up period.

\section{Conclusions}

Regardless of the form, histiocytosis may be accompanied by lesions within the maxillary bones, gingiva, and mucous membranes; therefore, dental examination should be a permanent element of diagnostic management.

\section{Authors' Contributions}

A. M.-R.: Research concept and design, supervising the project, carrying out the experiments, acquisition of data, analysis and interpretation of data, designing the figures, writing the manuscript, literature review, final proofreading and approval of the version for publication;

M. K.: Carrying out the experiments acquisition of data;

D. O.-K.: Research concept and design, supervising the project, carrying out the experiments, acquisition of data, analysis and interpretation of data designing the figures, drafting the article or revising it critically for important intellectual content, literature review, final proofreading and approval of the version for publication;
E. K.-S.: Research concept and design, supervising the project, carrying out the experiments, acquisition of data, analysis and interpretation of data, drafting the article or revising it critically for important intellectual content, literature review.

\section{Conflict of Interest}

The authors have no potential conflicts of interest to declare.

\section{Ethics Approval}

The research was carried out as part of a study of patients with neoplastic diseases, Approval No. 95/KBE/2010.

\section{References}

[1] Aricò M., Girschikofsky M., Généreau T., Klersy C., McClain K., Grois N., Emile J.F., Lukina E., De Juli E., Danesino C.: Langerhans cell histiocytosis in adults. Report from the International Registry of the Histiocyte Society. Eur. J. Cancer, 2003; 39: 2,3412,348

[2] Martínez D.S., Villagrán U.J., Ajqui R.R., Cervantes C.K.: Oral manifestations of Langerhans cell histiocytosis (LHC): Review of scientific literature and case report. Rev. Odontol. Mex., 2012; 16: 123-130

[3] Mortellaro C., Pucci A., Palmeri A., Lucchina A.G., Berta M., Celeste A., Costantino S., Del Prever A.B., Forni M.: Oral manifestations of Langerhans cell histiocytosis in a pediatric population: A clinical and histological study of 8 patients. J. Craniofac. Surg., 2006; 17: 552-556

[4] Olczak-Kowalczyk D., Kosiorowska-Bednarczyk A., Wakulińska A., Perek D.: Histiocytoza X - opis dwóch przypadków klinicznych. Czas. Stomatol., 2007; 60: 466-472

[5] Pogrzeba J., Rudkowska-Kazanowska A., Wróbel T.: Histiocytoza Langerhansa - problem diagnostyczny opis dwóch przypadków. Acta Haematol. Pol., 2005, 36: 441-446

[6] Yashoda-Devi B.K., Rakesh N., Agarwal M.: Langerhans cell histiocytosis with oral manifestations: A rare and unusual case report. J. Clin. Exp. Dent., 2012; 4: e252-e255

[7] Guyot-Goubin A., Donadieu J., Barkaoui M., Bellec S., Thomas C., Clavel J.: Descriptive epidemiology of childhood Langerhans cell histiocytosis in France, 2000-2004. Pediatr. Blood Cancer, 2008; 51: 71-75

[8] Ribeiro K.B., Degar B., Antoneli C.B., Rollins B., RodriguezGalindo C.: Ethnicity, race, and socioeconomic status influence incidence of Langerhans cell histiocytosis. Pediatr. Blood Cancer, 2015; 62: 982-987 
[9] Allen C.E., Merad M., McClain K.L.: Langerhans-Cell Histiocytosis. N. Engl. J. Med., 2018; 379: 856-868

[10] Badalian-Very G., Vergillo J.A., Degar B.A., MacConaill L.E., Brandner B., Calicchio M.L., Kuo F.C., Ligon A.H., Stevenson K.E., Kehoe S.M., et al.: Recurrent BRAF mutations in Langerhans cell histiocytosis. Blood, 2010; 116: 1,919-1,923

[11] Satoh T., Smith A., Sarde A., Lu H.C., Mian S., Trouillet C., Mufti G., Emile J.F., Fraternali F., Donadieu J., et al.: B-RAF mutant alleles associated with Langerhans cell histiocytosis, a granulomatous pediatric disease. PLoS One, 2012; 7: e33891

[12] Herwig M.C., Wojno T., Zhang Q., Grossniklaus H.E.: Langerhans cell histiocytosis of the orbit: Five clinicopathologic cases and review of the literature. Surv. Ophthalmol., 2013; 58: 330-340

[13] Davies H., Bignell G.R., Cox C., Stephens P., Edkins S., Clegg S., Teague J., Woffendin H., Garnett M.J., Bottomley W., et al.: Mutations of the BRAF gene in human cancer. Nature, 2002; 417: 949-954

[14] Berres M.L., Merad M., Allen C.E.: Progress in understanding the pathogenesis of Langerhans cell histiocytosis: Back to histiocytosis X? Br. J. Haematol., 2015; 169: 3-13

[15] Berres M.L., Lim K.P., Peters T., Price J., Takizawa H., Salmon H., Idoyaga J., Ruzo A., Lupo P.J., Hicks M.J., et al.: BRAF-V600E expression in precursor versus differentiated dendritic cells defines clinically distinct LCH risk groups. J. Exp. Med., 2014; 211: 669-683

[16] Allen C.E., Merad M., McClain K.L.: Langerhans-cell histiocytosis. N. Engl. J. Med., 2018; 379: 856-868

[17] Degar B.A., Rollins B.J.: Langerhans cell histiocytosis: Malignancy or inflammatory disorder doing a great job of imitating one? Dis Model Mech., 2009; 2: 436-439

[18] Aricò M., Astigarraga I., Braier J., Donadieu J., Gadner H., Glogova E., Grois N., Henter J.I., Janka G., McClain K.L., et al.: Lack of bone lesions at diagnosis is associated with inferior outcome in multisystem Langerhans cell histiocytosis of childhood. Br. J. Haematol., 2015; 169: 241-248

[19] Titgemeyer C., Grois N., Minkov M., Flucher-Wolfram B., Gatterer-Menz I., Gadner H.: Pattern and course of single-system disease in Langerhans cell histiocytosis data from the DAL-HX 83and 90-study. Med. Pediatr. Oncol., 2001; 37: 108-114
[20] Merglová V., Hrušák D., Boudová L., Mukenšnabl P., Valentová E., Hostička L.: Langerhans cell histiocytosis in childhood-review, symptoms in the oral cavity, differential diagnosis and report of two cases. J. Craniomaxillofac. Surg., 2014; 42: 93-100

[21] Bansal M., Srivastava V.K., Bansal R., Gupta V., Bansal M., Patne S.: Severe periodontal disease manifested in chronic disseminated type of Langerhans cell histiocytosis in a 3-year-old child. Int. J. Clin. Pediatr. Dent., 2014; 7: 217-219

[22] Hicks J., Flaitz C.M.: Langerhans cell histiocytosis: Current insights in a molecular age with emphasis on clinical oral and maxillofacial pathology practice. Oral Surg. Oral Med. Oral Pathol. Oral Radiol. Endod., 2005; 100: S42-S66

[23] Jalil A.B., Hin-Lau S.: Oral Langerhans cell histiocytosis in Malaysian children: A 40-year experience. Int. J. Paediatr. Dent., 2009; 19: 349-353

[24] Pekiner F.N., Borahan M.O., Özbayrak S., Alatlı C., Kızılyel G.: Oral manifestations of chronic disseminated Langerhans cell histiocytosis: A case report. Müsbed, 2012; 2: 138-142

[25] Gadner H., Minkov M., Grois N., Pötschager U., Thiem E., Aricò M., Astigarraga I., Braier J., Donadieu J., Henter J.I., et al.: Therapy prolongation improves outcome in multisystem Langerhans cell histiocytosis. Blood., 2013; 121: 5,006-5,014

[26] Li Z., Li Z.B., Zhang W., Li J.R., Wang S.P.., Cheng Y., Wei M.X.: Eosinophilic granuloma of the jaws: An analysis of clinical and radiographic presentation. Oral Oncol., 2006; 42: 574-580

[27] Kilic E., Er N., Mavili E., Alkan A., Gunhan O.: Oral mucosal involvement in Langerhans' cell histiocytosis: Long-term follow-up of a rare case. Aust. Dent. J., 2011: 56: 433-436

[28] Chi A.C., Neville B.W., Krayer J., Gonsalves W.C.: Oral manifestations of systemic disease. Am. Fam. Physician, 2010; 82: 1,381-1,388

[29] Joachimiak E., Włoga D., Filipek A., Fabczak H.: Ciliopatiechoroby spowodowane nieprawidłowym funkcjonowaniem rzęsek. Post. Bioch., 2018: 64: 338-350

[30] Eckardt A., Schultze A.: Maxillofacial manifestations of Langerhans cell histiocytosis: A clinical and therapeutic analysis of 10 patients. Oral Oncol., 2003; 39: 687-694 